\title{
ECONOMIC AND NONECONOMIC FORCES ON REMITTANCE RECEIVING: A PANEL ANALYSIS OF TOP REMITTANCE SENDING COUNTRIES TOWARDS BANGLADESH
}

(iD) Quazi Nur Alam ${ }^{1+}$
(i) Md Atiqullah
Khan $^{2}$

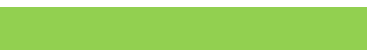

Article History

Received: 19 February 2021 Revised: 29 March 2021 Accepted: 3 May 2021 Published: 24 May 2021

\section{Keywords}

Remittance

Altruism

Macroeconomic variables

Crude oil price

FDI

Global financial crisis

$9 / 11$

$1 / 11$

Political unrest

Bangladesh.

\section{JEL Classification:} F24; N15; N35; O 15; O53.

\author{
'Lecturer, University of Information Technology \& Sciences, Bangladesh. \\ Email:quazishihab79@gmail.com Tel:+8801676529314 \\ ${ }^{\circ}$ Graduate Student, Department of Finance, University of Dhaka, \\ Bangladesh. \\ Email:writetoatiq@gmail.com Tel:+8801756539893
}

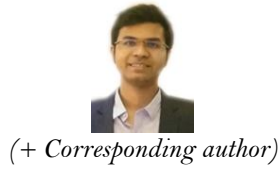

\begin{abstract}
The purpose of the paper is to investigate the impacts of economic and non-economic factors on the remittance receiving of Bangladesh. The study focuses on quantitative analysis of unbalanced panel data of 8 countries on remittance receiving of Bangladesh for the period of 1981-2019 by employing fixed effects model and random effects model. The results show that crude oil price, domestic credit to private sector of host country, and global financial crisis of 2008-10 have significant positive impact on remittance receiving of Bangladesh. GDP per capita of home country has significant negative impact which is an evidence of altruistic motive of migrant workers to remit more money. The impact of terrorist attacks on September 11, 2001 is found significantly positive as it resulted into strict change in monetary regulation by spreading more money from informal channel to formal channel. The political unrest in Bangladesh during 2007-08 has insignificant positive impact what means the non-democratic and army backed 1/11 government did not help to grow the remittance receiving. Inflation rate of host country has insignificant positive impact and FDI to GDP of host country has insignificant negative impact.
\end{abstract}

Contribution/Originality: This paper documents the altruistic motive of migrant workers to send more remittances. This is the first study which has investigated $1 / 11$ government effect on remittance receiving of Bangladesh. This paper adds value to the remittance related literature views. The findings can help to modify polices to increase remittance receiving.

\section{INTRODUCTION}

Income received from the migrant workers of many developing countries has become one of the largest sources of external financing and capital accumulation for gearing up the economic development, reducing poverty and increasing foreign exchange reserve (Abduvaliev \& Bustillo, 2019). Bangladesh is a developing market economy and currently it's $41^{\text {st }}$ largest economy in the world with an estimation of securing $24^{\text {th }}$ position by 2033 (The Daily Star, 2019). Bangladesh surprised the world by securing top position through achieving 188\% GDP growth whereas China achieved $177 \%$, India achieved $117 \%$, and Malaysia achieved $78 \%$ in world's GDP growth list in the last 10 years on the basis of current price method as per Spectator Index-2019 (Dhaka Tribune, 2019).

Remittance receiving of Bangladesh has a big contribution for such surprising economic growth. Bangladesh is in the $3^{\text {rd }}$ position in Asia and $11^{\text {th }}$ in the world in terms of remittance recipient of the world (The Daily Star, 2019). 
In 2018-19 FY, trade deficit of the country was USD 15.83 billion (Hasan, 2020). At the same fiscal year Bangladesh received USD 16.42 billion as remittances from migrant workers what strongly indicates that remittances massively help the country to balance the trade deficit (Hasan, 2020). In Bangladesh, personal remittances receiving as \% of GDP was 1.88\% in 1981 and the rate rose to 6.07\% in 2019 (World Bank Bangladesh Data, 2020).

As remittances are received in a country from many different parts of the world, economic factors influencing world economy have active influence on the remittance flows. While the countries are suffering in the pandemic of Covid-19, foreign exchange reserve of Bangladesh crossed the USD 40.0 billion benchmark amid coronavirus crisis for the first time in the history and inflow of remittances in Bangladesh shows an unbelievable surprise in the beginning of fiscal year 2020-21 (Harmachi, 2020). Thus the impact of home country's economic condition understood by GDP per capita is a point of investigation to realize whether the migrant workers remit the money for altruistic or portfolio motive.

Crude oil price movement hits almost in every aspect of economy. In Bangladesh, approximately $59 \%$ of total remittances is collected from middle-eastern countries which are the top exporters of crude oil (Mahmud, 2020). Different macro factors of host countries like inflation rate, foreign direct investment, and domestic credit to private sector influence migrant workers' remittance earnings have also influence over remittances. Global financial crisis in 2008-10 negatively hit the world resulting to an active impact on migrant workers' remitted money.

Different non-economic factors for example terrorist attacks on September 11, 2001 changed the existing financial rules and regulations of channeling money from one country to other countries. Thus existing literature found significant impact of this incident on remittance receiving of different countries. Bangladesh faced an unprecedented unrest during 2007-08 periods mostly known as '1/11' (One Eleven) because of an unexpected and surprising political shift. Whether there is any active impact of this home country's issue on remittance receiving from host countries is also a topic of investigation. So global financial crisis during 2008-10, terrorist attacks on September 11, 2001, and political crisis of Bangladesh during 2007-08 are tested as independent dummy variables on remittance receiving of Bangladesh.

The main purpose of this paper is to investigate which economic and non-economic factors have significant impact on the remittance receiving of Bangladesh from the migrant workers of remittance sending top 8 countries which are Kingdom of Saudi Arabia, Oman, Qatar, United Kingdom, United Sates of America, United Arab Emirates, Singapore, and Kuwait for the time period of 1981-2019. We use an unbalanced panel data of remittance sending top 8 countries to Bangladesh over the period of 1981-2019. This study involves the fixed effects model and random effects model and conducts Hausman test to choose appropriate model to observe the determinant factors influencing workers' remittance inwards. This paper will add value to the international remittance related literature reviews in the instances of developing and developed countries as well as assist to policy makers for forming the proper policies to smoothen the remittance income received from the migrant workers.

The study aims at these objectives:

(1) To understand the relationship between crude oil price and remittance receiving.

(2) To understand the relationship between GDP per capita of home country and remittance receiving.

(3) To understand the relationship between inflation rate of host country and remittance receiving.

(4) To understand the relationship between FDI net inflows of host country and remittance receiving.

(5) To understand the relationship between domestic credit to private sector and remittance receiving.

(6) To understand the relationship between global financial crisis during 2008-10 and remittance receiving.

(7) To understand the relationship between terrorist attacks on September 11, 2001 and remittance receiving.

(8) To understand the relationship between one eleven political unrest in Bangladesh in 2007-08 and remittance receiving. 
The second part of the paper covers reviews of existing literature reviews, the third part covers the data and methodology, the fourth part covers main empirical findings and the last part concludes the paper with policy recommendations. Thus this paper completes the investigation of the impacts of these economic and non-economic factors on remittance receiving of Bangladesh.

\section{LITERATURE REVIEW}

Except a few variables, there are sufficient supporting research studies to investigate the economic and noneconomic determinants that influence the remittance flow to the both developing and developed countries with the help of various econometric tools like pooled ordinary least squares, random effects models, fixed effect model, panel granger causality test. The previous studies on remittance researches are summarized here.

\subsection{Oil Price}

Many existing literature studies found that crude oil price has very active impact on economic activities including remittances. Naufal and Termos (2009) explored that middle-eastern countries' major revenues depend on oil business and any change in the crude oil price will affect in the remittance outflows where oil price elasticity to remittances is 40. Islam and Nasrin (2015) analyzed the driving forces of remittance inflows in Bangladesh by considering the period of 1977-2011. They found that GDP of host country, GDP of home country, exchange rate, petroleum price, and skill of labor have significant impact on remittance inflow in Bangladesh. Later, Umair and Waheed (2017) examined impact of host and home country's economic situation on remittance income to Pakistan from Saudi Arab and concluded that oil price shock is significant in the economy of Pakistan. Makhlouf and Kasmaoui (2017) carried out a study where oil price is the significant macroeconomic determinants of remittances and any change in the oil price has an exogenous shock in the economy of Morocco. Same result was found by Asatryan, Bittschi, and Doerrenberg (2017) after exploring price change in oil price is a strong determinant of inwards remittances receiving countries.

\subsection{GDP Per Capita of Home Country}

Several factors motivate the workers to remit the money. Home country's economic condition is one of these factors. Many studies used quantitative economic variables to find out home country's economic situation influencing migrant workers' remittances. Schiopu and Siegfried (2006) showed that altruism is important for remitting money as GDP differential between sending and receiving countries is positively correlated with average remittance of per migrant.

Barua, Majumder, and Akhtaruzzaman (2007) experimented panel data set of top most remittance sending countries of Bangladesh for the time period of 1993-2005 and concluded that there is availability of the investment and altruism motive to remit.

Later, Rahman and Wadud (2014) attempted to scrutinize the macroeconomic determinants of remittance inwards in South Asian countries by using systems of generalized method of moments (SGMM) method. They considered five countries of South Asia for the period of 176-2012. They found that remittance inwards in South Asia are motivated by altruism by the economic movement of home country by considering GDP per capita of home country and the relationship is significantly negative. Again self-interest motive is experienced in case of the economic condition of host country. Tabit and Moussir (2016) investigated different macroeconomic variables with a panel series of 22 developing countries for the period of 1994-2014. They found that origin country's GDP and host country's GDP have significant impact on migrants' remittances. Home country's GDP per capita has significant impact on migrants' remittance. It indicates that when home country suffers by adverse economic shocks, migrants are more willing to remit money to protect the well-being of their families. This is an evidence of altruism motive of the migrant workers. 
Hor and Pheang (2017) analyzed the macroeconomic variables and non-economic factors influencing the remittances of migrant workers of Cambodia, Myanmar, Laos, and Vietnam by considering the data period of 20002015. The study showed that GDP per capita of origin country, political stability index of home country, and official exchange rate of home country have significant negative impacts on remittance inflow to the chosen countries. But majors of host country's GDP per capita have positive effects on remittances. In the context of Bangladesh, Mustafa and Ali (2018) concluded that on the earnings of remittance GDP, inflation differentiation and altruism effect have the vital impact. In terms of middle income countries, Yoshino, Taghizadeh-Hesary, and Otsuka (2019) found that per capita gross domestic product growth in origin countries and wage rate in destination countries have positive impact on remittance inflows in middle income countries in Asia and the Pacific.

But, Lueth and Marta (2008) explored that the evidence on motives to remit is mixed and altruism might be less of factor than commonly believed. They also suggested that remittances may not perform expected major role in limiting vulnerability to the shocks.

\subsection{Inflation Rate}

Undoubtedly inflation of an economy impacts on the economic progression. Barua et al. (2007) found that home country's inflation is negatively correlated and host country's inflation is positively correlated with the inward remittances of Bangladesh. Thus Inflation differential between host and home country has negative impact on remittances.

On the other hand, in the study of Ncube and Brixiova (2013) it has been found that home country's inflation can negatively influence the inward remittance of home country. Later, Mukoswa (2016) investigated the effect of macro variables on the variations in diaspora remittances in Kenya. It has been found that inflation rate of home country has indirect impact on diaspora remittances. Rana and Hashmi (2015) reviewed the determinants in terms of foreign factors in the case of Bangladesh \& concluded that any change in the consumer price index will influence the remittance income of Bangladesh. Abbas, Masood, and Sakhawat (2017) found that inflation has significant negative impact on remittance inwards of Pakistan. The impact of inflation of host country on remittance receiving of home country is a gap in existing studies. Thus this is a topic of investigation in this study.

\subsection{FDI Net Inflows}

Existing studies showed that remittances create impact on FDI inflows. For example, Singala and Allamraju (2011) found a positive relationship between foreign direct investment and remittance income. Again some studies also showed that FDI inflows have impact on remittance receiving. Coon and Neumann (2017) analyzed how FDI inflows and remittance inflows are related. They found that FDI complements remittance and the relationship between remittances and FDI is the strongest for low income countries. It highlights that remittances are a source of investment capital in low income countries. On the other hand, Yoshino et al. (2019) used panel data of 12 Asia Pacific \& Middle East countries and came with a conclusion that foreign direct investment inflows are negatively correlated with the remittance inflows. No such existing study is found investigated the impact of FDI inflows of host country on the remittance receiving of home country.

\subsection{Domestic Credit to Private Sector}

Tabit and Moussir (2016) discovered that credit to private sector as a percentage of GDP of home country has significant negative impact on migrants' remittance receiving. But, Samuel, Odo, and Anoke (2018) found that international remittance inwards have positive insignificant relationship with domestic credit to private sector. Later Azizi (2020) analyzed a panel of 124 developing countries for the period of 1990-2015 and found that a 10\% increase in remittance to GDP ratio leads to $1.7 \%$ increase in domestic credit to private sector. Financial 
development fosters long term growth. No such study of the impact of domestic credit to private sector as percentage of GDP of host country on the remittance receiving of home country is found.

2.6. Global Financial Crisis

Global financial crisis during 2008-09 devastated the whole economy of the world. Ratha, Mohapatra, and Xu (2008) found that remittances are supposed to be remaining resilient in comparison with many other categories of resource flows to the developing countries. Adamu (2009) analyzed the influence of global financial crisis on Nigerian economy. He found that the financial crisis would fall into FDI inflow and decline remittances. Borja (2012) found that major disturbances to the US economy have a substantial and immediate impact on the remittances to El Salvador. Jha, Sugiyarto, and Vargas-Silva (2010) found that remittances to Asian countries in the Asian financial crisis dropped for short period of time but in the long run it was amplified in wide range. Mohapatra and Ratha (2010) explained in the book that the 2008-09 global financial crisis elevated the fears of a slowdown of remittance outflow and reversal of migration flows in the low income countries.

Bayangos and Jansen (2010) found that the impact on US recession on Philippine economy would lead to a significant slowdown in transferring of remittances. They also discovered that the economic cycle of main host countries drives the remittances. Raihan (2012) also explored that a growing apprehension in Bangladesh due to global financial crisis exists and the flow of international remittances to Bangladesh may get slowdown and it affects the economy adversely. In Latin American region, Borja (2012) found that US economy plays as an important factor by determining the level of remittances. Borja (2013) also showed that the economy of US plays a key role in determining the remittances of El Salvador and Dominican Republic. They found that out of international trade and FDI, remittances farther bound the nations to the US economy. Naude and Bezuidenhout (2014) found that remittances responded to natural disasters slowly, unresponsive to the outbreaks of conflict, and remittances would slowly decline following a systemic financial crisis.

\subsection{Terrorist Attacks on September 11, 2001}

Amjad, Irfan, and Arif (2013) found that 9/11 increased scrutiny and continued economic boom in the west as well as higher economic activities in the Middle East countries. As a result, the official remittances increased sharply. Later, Rahman and Wadud (2014) used panel data of five Asian countries over the time period of 19762012 and found the $9 / 11$ impact in remittance inflow is significantly positive. Due to the strict monetary regulations there was result of more receiving remittances through the formal channel as a replacement of informal channel. Same findings were received by Abbas et al. (2017) through employing GMM method to investigate the impact of macroeconomic and political factors on remittances of Pakistan by using data for a period of 1972-2012. They found that the terrorist attack of 2001 has significant positive impact on remittances.

\subsection{Impact of Political Unrest on the Economy and Remittance}

Jewel (2015) investigated the casual relationship between political stability and remittance inflows in Bangladesh. He found that political stability has positive impact on remittance inwards in Bangladesh both in the short run and the long run. At the same time, Rahman (2017) ran Probit regressions to estimate probable effects of emigration and remittance on the anti-incumbency of Upazila electorates in Bangladesh. They found that the probability of incumbent turnover is increased by an upward increase in quartile rank of the emigrant and remittance level. But Hor and Pheang (2017) investigated that political stability index of home country has significant negative impact on remittance inflow. They also showed that the military coup in Thailand during 200607 and 2014-15 had insignificant effect on remittance inflows to this region. No such existing study of the impact of $1 / 11$ political unrest in Bangladesh during 2007-08 on remittance receiving of Bangladesh is found.

All these studies identified different factors which have significant influence on remittance income. In addition to, there are influential factors like crude oil price, domestic credit to the private sector, foreign direct investment, 
and Political crisis during 2007-08, global financial crisis can significantly affect the remittances of Bangladesh. So, this research is necessary to fill up the gap and express the impact of these crucial determinants on remittances of Bangladesh. This research reviewed the wide range of panel data set of top 8 remittance sending countries to find out the significant economic and non-economic determinants on remittance income of Bangladesh. This paper uses mostly relevant variables and variables which have research gaps impacting on remittance receiving.

\section{ESTIMATION, DATA AND METHODOLOGY}

\subsection{Model and Estimation}

To understand the relationship between the dependent variable and the independent variables, the study was attempted with panel dataset. Fixed effects model and random effects model have been used in this study. The estimation of migrant workers' remittances received in Bangladesh is given below:

Rit $=\beta 0+\beta 1 * \mathrm{LOP}+\beta 2 * \mathrm{LYKHM}+\beta 3 * \mathrm{INFHS}+\beta 4 * \mathrm{FDI}+\beta 5 * \mathrm{DCPS}+\gamma 1 * \mathrm{D} 1 \mathrm{GFC}+\gamma 2 * \mathrm{D} 2 \mathrm{NE}+\gamma 3 * \mathrm{D} 3 \mathrm{OE}+$ Eit

Where, the dependent variable, Rit means migrant remittances received in Bangladesh as \% of GDP.

$\beta 0$ indicates the constant of this model;

$\beta 1, \beta 2, \ldots \beta 5$ are the coefficients to be estimated according to the independent variables;

$\gamma 1, \gamma 2$, and $\gamma 3$ are the coefficients to be estimated according to dummy variables;

LOP $=$ Natural log of crude oil price;

LYKHM = Natural log of GDP per capita of home country;

INFHS = Inflation rate of host country;

FDI $=$ FDI net inflows as \% of GDP;

DCPS $=$ Domestic credit to private sector as \% GDP;

D1GFC = Dummy variable for global financial crisis during 2008-10;

$\mathrm{D} 2 \mathrm{NE}=$ Dummy variable for terrorist attack of 9/11 on September 11, 20001;

$\mathrm{D} 3 \mathrm{OE}=$ Dummy variable for political crisis of 1/11 in Bangladesh during 2007-08;

$\varepsilon$ indicates the error term of this equation and the $t$ indicates the specific period.

3.2. Data

The study applied an unbalanced panel data of top remittance sending countries to Bangladesh with a total no. of observations of 301. The study chose 8 countries for the data period of Kingdom of Saud Arabia (1981-2017), Kuwait (1981-2018), Oman (1981-2018), Qatar (1981-2019), UAE (1981-2018), Singapore (1983-2019), UK (20812019), and USA (1981-2019). For conducting the study, data were collected from World Bank, The Global Economy, Statista, and other sources.

\subsection{Dependent Variable}

\subsubsection{Migrant Remittances Received as \% of $G D P(R)$}

Remittance received from migrant workers from each country as \% of GDP of home country has been chosen as the dependent variable for the study. Personal remittance of migrant workers received as \% of GDP is a strong indication to understand the trend of remittance inwards from the chosen countries.

\subsection{Independent Variables}

All the chosen independent variables are divided into two categories. LOP, LYPHM, INFHS, FDI, DCPS, and D1GFC are economic variables whereas $\mathrm{D} 2 \mathrm{NE}$ and $\mathrm{D} 2 \mathrm{OE}$ are non-economic variables. These variables are described below: 


\subsubsection{Crude Oil Price (LOP)}

Crude oil price is considered to be the most crucial price in the world as it tells not only what's going on in world economy but also what may happen in future. Crude oil is also the most important energy of the world. Most of the oil is used in transportation but it is also used in manufacturing almost all the chemical products. Economic advances with the passage of time have increased the demand of it. Thus oil price plays vital role in economic movement in each country. Therefore, the price of oil hits countries dependent on remittances. Brent crude, West Texas Intermediate (WTI), and OPEC crude oil are three major benchmark crude oil prices which serve as reference prices for both the buyers and sellers. As per relevance of data, natural log of annual average price of Brent crude oil has been used for Oman, Singapore, and UK (Average UK Brent oil price 1976-2019 | Statista (2020). Natural log of annual average price of West Texas Intermediate (WTI) has been used for The USA (West Texas Intermediate oil price annually 1976-2020 | Statista (2020). And Natural log of annual average price of OPEC crude oil has been used for Kingdom of Saudi Arab, Kuwait, United Arab Emirate, and Qatar (OPEC oil prices 1960-2020 | Statista (2020).

\subsubsection{GDP Per Capita of Home Country (LYKHM)}

Gross Domestic Product per capita is a great indicator to understand the economic condition of an economy. It's a measurement of a country's output which accounts for its number of people. Migrants who left home country to foreign countries send the remittances to home country basically for two purposes. One is altruistic motive and another is portfolio motive. The relationship between GDP per capita of home country and remittances received by home country is a vital point to understand whether the migrants remit money to home country for altruistic or portfolio motive. Natural log of GDP per capita of home country Bangladesh has been used in this study to examine the actual motive of the migrants.

\subsubsection{Inflation (INFHS)}

Inflation erodes the purchasing power, encourages higher spending and more investing, causes farther inflation, changes the cost of borrowing, increases growth, results to create more employment, weakens or strengthens the currency. Thus inflation of host country has an active impact on migrant earnings which results into an influence on remitted money to home country. Inflation rate derived from consumer price indices of host countries has been used in the study.

\subsubsection{Foreign Direct Investment Net Inflows, \% of GDP (FDI)}

Foreign Direct Investment (FDI) exerts a positive impact on host country's economic growth. When the economy expands, new jobs are created and wage rate increases resulting to an increase on migrants' remittance earnings. Foreign direct investment net inflows to GDP ratio is a great measurement for understanding this which has been applied in the study.

\subsubsection{Domestic Credit to Private Sector, \% of GDP (DCPS)}

Domestic credit to private sector indicates the financial resources given to private sector by establishing a claim for repayment. By tapping the private sector initiatives and investments, domestic credit to private sector has tremendous potential on economic growth. Thus domestic credit to private sector as \% of GDP has been considered to understand its impact on migrants' remittance earnings.

\subsubsection{Global Financial Crisis during 2008-10 (D1GFC)}

The global economic downturn was caused by great recession in 2008 devastating the world financial markets including banking and real estate markets. Many people lost their jobs. Many countries were severely affected by it. 
Thus this dummy variable measuring the effects of US recession for the period of 2008-10 has been chosen to understand its impact on the remittance inwards of Bangladesh.

\subsubsection{Terrorist Attack of $9 / 11$ on September 11, 2001 (D2NE)}

The terror attack happened on September 11, 2001 mostly known as '9/11' (Nine Eleven) created rippling effects on economy through having negative impacts. By turning market economy uncertain, huge loss in tourism, and xenophobia, the terror attack badly affected whole world created an active impact on remittances (Ross, 2019). In reaction, governments took many steps to stop the money transacted inter countries for channeling towards terrorist funding. Legal systems were modified and policies were designed to secure money transfer across the countries. As migrants were supposed to use more formal channels to remit the money, it resulted in an increase on the remittance receiving of home countries. To understand this effect on remittance inwards, the terrorist attack on September 11, 2001 has been chosen as a dummy variable. Whether there is an increase of the migrants' remittances sent to home country after 2001 terrorist attack is also a topic of investigation in this study.

\subsubsection{Political Crisis in Bangladesh of $1 / 11$ during 2007-08 (D3OE)}

A hitting political crisis was originated as a conflict of caretaker government accumulated power in Bangladesh at the end of October, 2006 (Chowdhury, 2013). On January 11, 2007, the democracy of Bangladesh was questioned and turned into an unprecedented crisis stage. Top two leaders who were the top leaders of two major parties were arrested. These arrested two leaders were the former prime ministers of the country's government in different regime periods. Finally, parliamentary democracy was restored after two years long political crisis. The political unrest during 2007-08 was home country specific and it has been chosen as another dummy variable to understand its effect on remittance receiving of Bangladesh during this period.

\subsection{Measurement of the Chosen Variables}

The Table 1 shows the formulae which have been used for the variables in this research. Here, $\mathrm{R}$ indicates the dependent variable and the rest are independent variables.

Table-1. Formulae of the chosen variables.

\begin{tabular}{l|l}
\hline Variable & Measurement \\
\hline R & (Remittance receiving in Bangladesh from each country/GDP)* 100 \\
\hline LOP & Natural log of Crude oil price \\
\hline LYPH & Natural log of GDP per capita of Bangladesh \\
\hline INFHS & $((\text { CPIt - CPIt-1)/ CPIt-1 }))^{*} 100$ \\
\hline FDI & $(\text { FDI net inflows/ GDP })^{*} 100$ \\
\hline DCPS & $(\text { Domestic credit to private sector/ GDP })^{*} 100$ \\
\hline D1GFC & Year $(2008-10)=1$ and for other years $=0$ \\
\hline D2NE & For, (Year $1981-2001=0)$ and $($ Year $2002-2019=1)$ \\
\hline D2OE & Year $(2007-08)=1$ and for other years $=0$ \\
\hline
\end{tabular}

\section{ANALYSIS AND FINDINGS}

The findings shown on Table 2 provide the results of fixed effects model and random effects model. Hausman test result shows that fixed effects model is suitable for the study.

The results of the study highlight several facts. The coefficient associated with oil price (LOP) is positive and significant what indicates an increase in oil price creates a positive impact on remittance receiving of Bangladesh. Because of the increase in crude oil price, major host countries need more labor for gearing up the development activities which are financed by the surplus oil revenues. The finding supports (Asatryan et al., 2017; Islam \& Nasrin, 2015; Naufal \& Termos, 2009; Umair \& Waheed, 2017). 
The Economics and Finance Letters, 2021, 8(2): 201-212

Table-2. Fixed effects model, random effects model and hausman test

\begin{tabular}{|c|c|c|c|c|c|c|}
\hline \multirow{2}{*}{$\begin{array}{l}\text { Model } \\
\mathbf{R}\end{array}$} & \multicolumn{3}{|c|}{ Fixed Effects Model } & \multicolumn{3}{|c|}{ Random Effects Model } \\
\hline & Coef. & t-statistic & p value & Coef. & z-statistic & p value \\
\hline LOP & $0.1528 * * *$ & 3.04 & 0.003 & $0.1457 *$ & 1.70 & 0.088 \\
\hline LYPH & $-0.0999 *$ & -1.79 & 0.075 & -0.0257 & -0.29 & 0.769 \\
\hline INFHS & 0.0015 & 0.20 & 0.844 & $-0.0271 * * *$ & -2.40 & 0.016 \\
\hline FDI & -0.0051 & -0.87 & 0.383 & $-0.0280 * * *$ & -5.25 & 0.000 \\
\hline DCPS & $0.0037 * * * *$ & 3.55 & 0.000 & -0.0009 & -1.44 & 0.149 \\
\hline D1GFC & $0.2420^{* * * *}$ & 3.49 & 0.001 & $0.2937 * * *$ & 2.49 & 0.013 \\
\hline $\mathrm{D} 2 \mathrm{NE}$ & $0.2438 * * *$ & 3.34 & 0.001 & $0.3322 * * *$ & 2.69 & 0.007 \\
\hline D3OE & 0.0243 & 0.27 & 0.789 & 0.2284 & 1.51 & 0.132 \\
\hline Constant & 0.1936 & 0.66 & 0.509 & 0.1998 & 0.40 & 0.687 \\
\hline R Square & $45.85 \%$ & & & $38.29 \%$ & & \\
\hline $\mathrm{F}(8,298)$ & $30.16^{* * * *}$ & & 0.000 & & & \\
\hline Wald chi 2 & & & & 108.05**** & & 0.000 \\
\hline Hausman Test & $75.72 * * * *$ & & 0.000 & & & \\
\hline
\end{tabular}

GDP per capita of home country (LYKHM) has significant negative impacts on the remittance receiving of Bangladesh. The result is an evidence of altruistic motive instead of portfolio motive of the migrant workers. It means migrant workers works at different countries are motivated by altruism to remit more money to their families during the economic downturn in home country. They do it basically to protect their families from unusual lower income of the family. Similar results were found by Schiopu and Siegfried (2006); Barua et al. (2007): Rahman and Wadud (2014); Tabit and Moussir (2016); Hor and Pheang (2017) and Mustafa and Ali (2018). But the result varies from the findings of Lueth and Marta (2008).

Inflation rate of host countries (INFHS) has positive but insignificant impact on remittance receiving of Bangladesh. It means an increase in inflation of the host country increases remittance inflows of the home country but the relationship is weak. The finding partially supports the finding of Barua et al. (2007).

Here a foreign direct investment inflow to GDP ratio (FDI) is negative means higher FDI inflows to host country reduce the remittance inflows in home country but the relationship isn't significant.

The domestic credit to private sector as percentage of GDP (DCPS) has significant positive impact on remittance inwards of home country. It means higher credit in domestic sector of host country increases the remittance inflows to the home country.

Global financial crisis (D1GFC) had significant positive impact on remittance inwards of Bangladesh which is also another evidence of altruism motive of the workers for the families lived in home country during the economic uncertainty of the world in 2008-10. The finding supports (Jha et al., 2010; Ratha et al., 2008) but varies from Adamu (2009); Raihan (2012); Naude and Bezuidenhout (2014).

The terrorist attack of 2001 is mostly known as '9/11' (D2NE) influenced the whole world economy by putting an urge to modify foreign transactions and channeling the money flows. The significant positive impact of $9 / 11$ on remittance inwards of Bangladesh indicates that the improved regulations of US and migrant host countries discouraged migrants from using the informal channels to remit their earnings to home country. The finding supports (Abbas et al., 2017; Amjad et al., 2013; Rahman \& Wadud, 2014). 1/11 political unrest in Bangladesh during 2007-08 (D3OE) had positive impact on remittance but the insignificant impact indicates that remittance receiving of Bangladesh isn't strongly influenced by political instability. It also means that non-democratic army backed 1/11 government didn't help to grow remittance receiving of Bangladesh. This finding varies from Hor and Pheang (2017) in terms of military intervention in a country.

\section{CONCLUSIONS}

This paper investigates the impacts of economic and non-economic factors on the migrant remittances receiving of Bangladesh through conducting panel data analysis of remittance sending top 8 countries. The 
empirical study is conducted with unbalanced panel dataset for the period of 1981-2019. Hausman test result shows that fixed effects model is appropriate for the study. The findings show that crude oil price, GDP per capita of home country, domestic credit to private sector, global financial crisis during 2008-10, and terrorist attack on September 11, 2001 have significant impact on remittance inwards in Bangladesh. Migrant workers are motivated by altruism to remit more money to their families in Bangladesh when there are economic downturns. But migrant workers don't react significantly by the changes in inflation rate of host country, FDI inflows in host country, and political unrest of home country. The study has a limitation of considering only 8 countries while the country receives remittances from many other countries. Some other factors couldn't be considered due to unavailability of data for some periods. This paper could still be improved into these various directions by availing the data. A cross comparison with neighboring countries may give better insight.

\section{POLICY IMPLICATIONS AND RECOMMENDATIONS}

The findings of the study benefit policymakers by making aware about both economic and non-economic factors influencing on remittance receiving of Bangladesh. Remittance receiving of Bangladesh largely depends on altruism as per evidence of GDP per capita of home country and global financial crisis. Thus policy makers of Bangladesh should design pro-growth and investment policies to create additional jobs in home country. As crude oil price has very active impact on remittance receiving, policymakers should be more vigilant about global oil price movements. Policymakers should try to send migrants to those countries having higher contribution of domestic credit to private sector. Government should try to design the regulatory policies in such way that triggers the migrant workers to remit the money via using formal channel instead of informal channel.

Funding: This study received no specific financial support.

Competing Interests: The authors declare that they have no competing interests

Acknowledgement: Both authors contributed equally to the conception and design of the study.

\section{REFERENCES}

Abbas, F., Masood, A., \& Sakhawat, A. (2017). What determine remittances to Pakistan? The role of macroeconomic, political and financial factors. Journal of Policy Modeling, 39(3), 519-531. Available at: https://doi.org/10.1016/j.jpolmod.2017.03.006.

Abduvaliev, M., \& Bustillo, R. (2019). Impact of remittances on economic growth and poverty reduction amongst CIS countries. Post-Communist Economies, 32(4), 525-546.

Adamu, A. (2009). The effects of global financial crisis on Nigerian economy. International Journal of Investment and Finance, $1(1 \& 2), 11-21$.

Amjad, R., Irfan, M., \& Arif, G. (2013). How to increase formal inflows of remittances: An analysis of the remittance market in Pakistan (pp. 1-58). Pakistan: International Growth Centre.

Asatryan, Z., Bittschi, B., \& Doerrenberg, P. (2017). Remittances and public finances: Evidence from oil-price shocks. Journal of Public Economics, 155, 122-137. Available at: https://doi.org/10.1016/j.jpubeco.2017.09.009.

Azizi, S. (2020). Impacts of remittances on financial development. Journal of Economic Studies, 47(3), 467-477. Available at: https://doi.org/10.1 108/JES-01-2019-0045.

Barua, S., Majumder, M., \& Akhtaruzzaman, M. (2007). Determinants of workers' remittances in Bangladesh: An empirical study. Policy Analysis Unit (PAU), Bangladesh Bank Working Paper No. WP, 713.

Bayangos, V., \& Jansen, K. (2010). The macroeconomics of remittances in the Philippines. Ensayos Sobre Politica Economica, $28(\mathrm{SPE} 61), 18-58$.

Borja, K. (2012). The impact of the US Recession on immigrant remittances in Central America. Journal of International Commerce, Economics and Policy, 03(03), 1250020. 
Borja, K. (2012). What drives remittances to Latin America? A review of the literature. International Journal of Business and Social Science, 3(17), 33-44.

Borja, K. (2013). Home and host country business cycles and remittances: The case of El Salvador and the Dominican Republic. Applied Econometrics and International Development, 13(2), 101-118.

Chowdhury, M. (2013). A blot called '1/11'. Retrieved from: https://bdnews24.com/bangladesh/2013/01/11/a-blot-called-111. [Accessed 13 August 2020].

Coon, M., \& Neumann, R. (2017). Follow the money: Remittance responses to FDI Inflows. Journal of Globalization and Development, 8(2), 1-20.

Dhaka Tribune. (2019). Bangladesh achieves top position in world's GDP growth list. Retrieved from: https://www.dhakatribune.com/business/2019/09/02/bangladesh-achieves-top-position-in-world-s-gdp-growth-list.

Harmachi, A. (2020). Bangladesh's forex reserves top $\$ 40 b n$ on remittance inflow. Bdnews24.com, Retrieved from: https://bdnews24.com/economy/2020/10/08/bangladeshs-forex-reserves-top-40bn-on-remittance-inflow.

Hasan, M. (2020). Trade deficit widens to $12.79 \%$ in FY20. Dhaka Tribune, Retrieved from: https://www.dhakatribune.com/business/2020/07/28/trade-deficit-widens-to-12-79-in-fy20.

Hor, C., \& Pheang, P. (2017). Analysis determinant factors effect on migrant workers' remittances flow to the CLMV Countries. International Journal of Economics and Financial Issues, 7(2), 202-207.

Islam, M. S., \& Nasrin, S. (2015). Driving forces of remittance inflow in Bangladesh: An empirical study. International Journal of Economics and Finance, 7(6), 126-138.

Jewel, F. R. (2015). Political Stability, foreign direct investment and remittance inflow in Bangladesh: An empirical Analysis. Masters. Saint Mary's University.

Jha, S., Sugiyarto, G., \& Vargas-Silva, C. (2010). The global crisis and the impact on remittances to developing Asia. Global Economic Revierw, 39(1), 59-82. Available at: https://doi.org/10.1080/12265081003696395.

Lueth, E., \& Marta, R.-A. (2008). Determinants of bilateral remittance flows. The BE Journal of Macroeconomics, 8(1), 1-23.

Mahmud, M. (2020). Middle East dual shock spillover on Bangladesh's remittance. The Business Standard, Retrieved from: https://tbsnews.net/thoughts/middle-east-dual-shock-spillover-bangladeshs-remittance-108325.

Makhlouf, F., \& Kasmaoui, K. (2017). The impact of oil price on remittances. The Journal of Energy and Development, 43(1/2), 293310.

Mohapatra, S., \& Ratha, D. (2010). The impact of the global financial crisis on migration and remittances. The Day After Tomorrow: A Handbook on the Future of Economic Policy in the Developing World (pp. 297-320). Washington DC: World Bank.

Mukoswa, O. (2016). Macroeconomic variables and variations in Diaspora Remittances in Kenya. Pressacademia, 5(2), 156-164. Available at: https://doi.org/10.17261/pressacademia.2016219258.

Mustafa, K., \& Ali, S. R. (2018). The macroeconomic determinants of remittances in Pakistan. International Journal of Business Management and Finance Research, 1(1), 1-8.

Naude, W. A., \& Bezuidenhout, H. (2014). Migrant remittances provide resilience against disasters in Africa. Atlantic Economic Journal, 42(1), 79-90. Available at: https://doi.org/10.1007/s1 1293-014-9403-9.

Naufal, G. S., \& Termos, A. (2009). The responsiveness of remittances to price of oil: The case of the GCC. OPEC Energy Review, 33(3-4), 184-197.

Ncube, M., \& Brixiova, Z. (2013). Remittances and their macroeconomic impact: evidence from Africa. African Development Bank Group Working Paper, No. 188.

Rahman, S. (2017). Does remittance affect local democracy in developing countries? Evidence from local elections in Bangladesh. Working Paper. Available at: 10.13140 RG.2.2.14436.17280.

Rahman, S., \& Wadud, M. (2014). Macroeconomic determinants of remittances in South Asian countries: a dynamic panel study. In: Rethinking Political Economy and Development (pp. 1-18). Dhaka: Bangladesh Economic Association (BEA). 
Raihan, S. (2012). Global Financial crisis, remittances, exports and poverty in Bangladesh. Paper presented at the Dhaka: South Asian Network on Economic Modeling (SANEM).

Rana, R. H., \& Hashmi, R. (2015). The determinants of worker remittance in terms of foreign factors: The case of Bangladesh. Studies in Business and Economics, 1O(3), 81-93. Available at: https://doi.org/10.1515/sbe-2015-0038.

Ratha, D., Mohapatra, S., \& Xu, Z. (2008). Outlook for remittance flows 2008-2010: Growth expected to moderate significantly, but flows to remain resilient. Migration And Development Brief, 8(1), 1-14.

Ross, S. (2019). Top 5 ways terrorism impacts the economy. Investopedia. Retrieved from: https://www.investopedia.com/articles/markets/080216/top-5-ways-terrorism-impacts-economy.asp.

Samuel, O. O., Odo, S. I., \& Anoke, C. I. (2018). Remittance inflow and domestic credit to private sector: The Nigerian experience. IOSR Journal of Business and Management (IOSR-JBM), 2O(1), 28-38.

Schiopu, I., \& Siegfried, N. (2006). Determinants of workers' remittances: Evidence from the European neighbouring region (October 2006). ECB Working Paper No. 688, Available at SSRN: https://ssrn.com/abstract=936947.

Singala, S., \& Allamraju, A. (2011). The economics of migrant workers' remittances to India. ASCI Journal of Management, 4O(1), 17-30.

Statista. (2020). Average UK Brent oil price 1976-2019 | Statista. Retrieved from: https://www.statista.com/statistics/262860/uk-brent-crude-oil-price-changes-since-1976/.

Statista. (2020). OPEC oil prices 1960-2020 | Statista. Retrieved from: https://www.statista.com/statistics/262858/change-inopec-crude-oil-prices-since-1960/.

Statista. (2020). West texas intermediate oil price annually 1976-2020 | Statista. Retrieved from: https://www.statista.com/statistics/266659/west-texas-intermediate-oil-prices/.

Tabit, S., \& Moussir, C.-E. (2016). Macroeconomic determinants of migrants' remittances: Evidence from a panel of developing countries. International Journal of Business and Social Research, 6(7), 1-11. Available at: https://doi.org/10.18533/ijbsr.v6i7.969.

The Daily Star. (2019). Bangladesh 2nd largest economy in South Asia. Retrieved from: https:// www.thedailystar.net/bangladesh/bangladesh-ranked-41st-largest-economy-in-2019-all-over-the-worldstudy-1684078.

Umair, M., \& Waheed, A. (2017). What drives remittances from Saudi Arabia to Pakistan? Home versus host country's economic conditions. International Migration, 55(4), 141-153. Available at: https://doi.org/10.1111/imig.12344.

World Bank Bangladesh Data. (2020). Personal remittances, received (\% of GDP) - Bangladesh | Data. (2020). Retrieved from: https://data.worldbank.org/indicator/BX.TRF.PWKR.DT.GD.ZS?locations=BD. [Accessed 22 August 2020].

Yoshino, N., Taghizadeh-Hesary, F., \& Otsuka, M. (2019). Determinants of international remittance inflows in middle-income countries in Asia and the pacific. ADBI Working Paper, No. 964.

Views and opinions expressed in this article are the views and opinions of the author(s), The Economics and Finance Letters shall not be responsible or answerable for any loss, damage or liability etc. caused in relation to/arising out of the use of the content. 